\title{
A REVIEW OF NESTING BEHAVIOR IN THE GENUS ENTOMOGNATHUS, WITH NOTES ON E. MEMORIALIS BANKS (HYMENOPTERA： SPHECIDAE)
}

\section{By Richard C. Miller and Frank E. Kurczewski ${ }^{1}$}

The genus Entomognathus contains at least 40 species, half in the Ethiopian and in the Palaearctic, Nearctic, Oriental, and Neotropical regions (Leclercq, 1954, 1955, 1961, 1963; Nouvel and Ribaut, 1956; Krombein, 1963). Relatively little is known about the nesting behaviors, host preferences, or life histories of members of this genus. Only the Palaearctic E. (Entomognathus) brevis van der Linden has been studied in any detail, and almost nothing is known about the four U. S. species belonging to the subgenus Toncahua. One of the purposes of the present paper is, therefore, to amalgamate information on the host preferences, nesting behaviors, life histories, and immature stages of the species of Entomognathus, based upon a review of the world literature. The major portion of this paper details the components of the nesting behavior of $E$. (Toncahua) memorialis Banks, describes the mature larva and cocoon, and compares this species and related crabronine and larrine wasps in nesting ethology and larval and cocoon morphology. The adult wasps and prey beetles have been placed in the S. U. N. Y. College of Forestry Insect Museum, and the mature larva has been deposited in the Museum of Comparative Zoology, Harvard University.

\section{Entomognathus (Mashona) mimicus Arnold}

One female from Bekily, Madagascar was observed by Arnold ( 1944) preying upon a small chrysomelid beetle.

Entomognathus (Mashona) patricius Arnold

Arnold ( I932) reported several females nesting in a clay bank beside a stream in Bulawayo, S. Rhodesia. The wasps were preying upon a species near Ootheca modesta Gahan (Chrysomelidae: Galerucinae).

Entomognathus (Entomognathus) brevis v. d. Lind.

This widely distributed Palaearctic species has been reported to nest in sand, gravel, clay, and chalky-loam, and to burrow in hori-

\footnotetext{
${ }^{1}$ Department of Forest Entomology, State University College of Forestry, Syracuse, New York 13210.

Manuscript received by the editor July 5, 1972.
} 
zontal and vertical situations as well as in depressions (Chambers, 1949). E. brevis has been known to nest in or near woodlands (Grandi, I927; Chambers, I949), and to aggregate (Benoist, I915). According to Adlerz (I9I2), females were observed to enter the burrows of other wasps, remain for only a moment, and exit, but it was not ascertained whether the wasps used pre-existing burrows for nest-sites.

The females have been noted to construct earthen, chimney-like extensions of the burrows, IO-25-mm-long, above the ground surface (Benoist, I9I5; Grandi, 1927, I93I), or to make no such extensions (Maneval, I928, I937; Abrahamsen, r95I). Grandi (I93I) found nests with and without turrets in the same area. The main burrow, 2-3 $\mathrm{mm}$ in diameter, plunged obliquely downward, sometimes circumventing subterranean obstacles, and at depths of 6-r2 $\mathrm{cm}$ branched into side burrows leading to the cells; the oval cells, 4. $\times 8 \mathrm{~mm}$, were located at depths of $6-\mathrm{I} 2 \mathrm{~cm}$ beneath the surface (Grandi, I927; Maneval, 1928; Abrahamsen, I95I), the maximum number per nest being ten (Benoist, I915).

The wasps transported their prey in flight, holding it with the middle legs, and hovered back and forth in front of the entrance before diving inside (Adlerz, I9I2).

Seven genera and seventeen species of Chrysomelidae have been reported as prey of $E$. brevis (Table I). All are members of the subfamily Alticinae except Cryptocephalus labiatus L. (Cryptocephalinae). In one of the earliest reports on this species, Sickmann (I893) recorded small flies as prey; however, this record was probably based upon a misidentification of the wasp. The prey are never killed by the wasp but invariably paralyzed (Benoist, I9I5; Grandi, I927, I931; Maneval, 1928; Abrahamsen, I95I).

Both Maneval (I928) and Grandi (I93I) noted that large and small chrysomelids were captured by the wasps. The number of prey stored per cell ranged from 14 to 24 . From one to four genera and species were stored in a single cell, and at least two and usually three or four species were captured at all but one of the several localities where more than one prey was collected (Benoist, I9I5; Hamm and Richards, I926; Grandi, I927, I931 ; Maneval, I928, I937; Richards, I944; Abrahamsen, I95I).

According to Grandi (1927) and Maneval (1928), the wasp did not lay her egg until the full complement of prey had been put in the cell. Maneval ( 1937) found prey near the bottom of the nest in a section of the burrow, 3-4-cm-long, but he did not note an egg attached to any of the beetles. In fully-provisioned cells, the beetles 
TABLE I. Species of prey of Entomognathus brevis.

\begin{tabular}{|c|c|}
\hline Genus and species of prey & Source \\
\hline Aphthona euphorbiae Schrank & Grandi, I93I \\
\hline Aphthona herbigrada Curtis & Grandi, I927; Maneval, 1937 \\
\hline Aphthona pygmaea nigella Kutsch. & Grandi, I93I \\
\hline Chaetocnema arida Foudras & Maneval, I937 \\
\hline Chaetocnema concinna Marsham & Richards, I944 \\
\hline $\begin{array}{l}\text { Chaetocnema hortensis Geoffroy } \\
\qquad(=\text { aridella Paykull })\end{array}$ & $\begin{array}{l}\text { Grandi, I93I ; Richards, I944; } \\
\text { Abrahamsen, I95 I }\end{array}$ \\
\hline Chalcoides aurata Marsham & Richards, I944 \\
\hline Crepidodera ferruginea Scopoli & $\begin{array}{l}\text { Maneval, I928; Bouwman, I930; } \\
\text { Grandi, I931 ; Chambers, I949; } \\
\text { Abrahamsen, I95 I }\end{array}$ \\
\hline Cryptocephalus labiatus Linnaeus & Hamm and Richards, 1926 \\
\hline Longitarsus jacobaeae Waterhouse & Hamm and Richards, 1926 \\
\hline Longitarsus luridus Scopoli & Adlerz, I9I2 \\
\hline Longitarsus nasturtii Fabricius & Abrahamsen, I95 I \\
\hline Longitarsus pellucidus Foudras & Grandi, I927 \\
\hline Longitarsus pratensis Panzer & $\begin{array}{l}\text { Grandi, I927, I93I; } \\
\text { Maneval, I937 }\end{array}$ \\
\hline Longitarsus succineus Foudras & Maneval, I928; Grandi, r93 I \\
\hline Longitarsus suturalis Marsham & Maneval, I937 \\
\hline Phyllotreta nigripes Fabricius & Grandi, I93I \\
\hline Phyllotreta sp. & Benoist, I915 \\
\hline
\end{tabular}

were piled indiscriminately with the egg-bearer, ventral-side-upward, on top of the pile; the wasp's egg was attached to the venter of the beetle at the mesal base of the forecoxa, and extended transversely beyond the side of the beetle (Grandi, 1927). It was elongate, subcylindrical, curved, and measured $2 \times 3 / 4 \mathrm{~mm}$.

The cocoon of $E$. brevis has been reported to be thin-walled and to measure 4.5-6 $\times 2.3 \mathrm{~mm}$ (Benoist, 1915). According to this author, the mature larva pushed the uneaten prey fragments to one end of the cell rather than distributing them over the surface of the cocoon. The larva pupated in June of the following year and the adult appeared during the second half of July. Adult wasps have been collected in Europe from the second week in June (Chambers, 1949) to the second week in September (Grandi, 1927).

\section{Entomognathus (Toncahua) texana Cresson}

Cazier and Mortenson (1965) collected one female flying above 


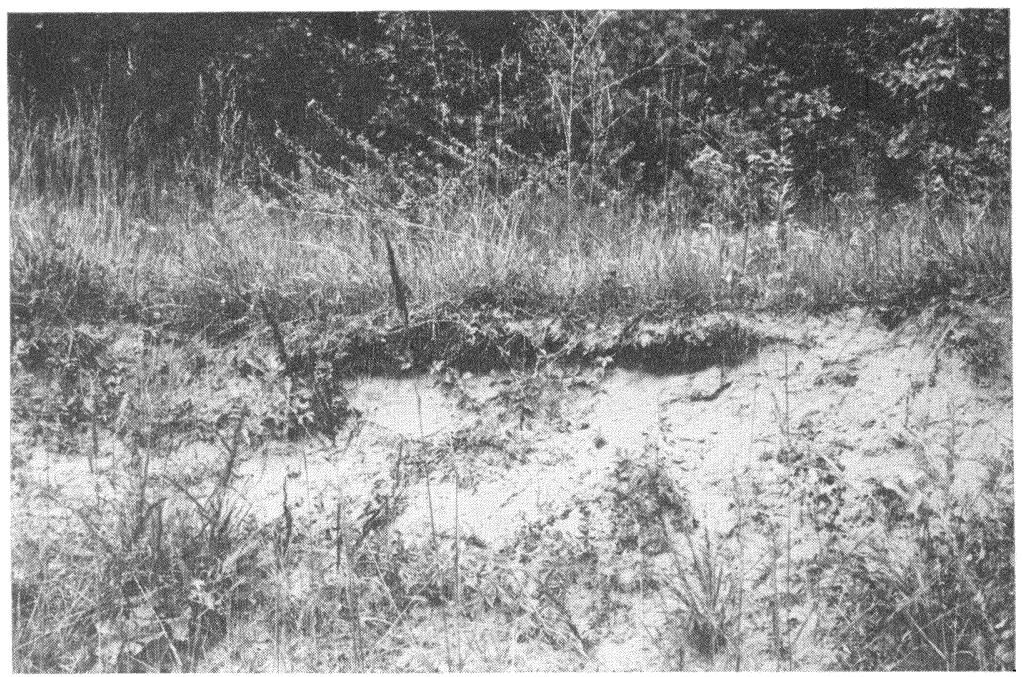

Fig. 1. Nesting-site of E. memorialis Banks at Chittenango, N. Y. Individual nests occupied the upper portion of cliff, among roots.

a sandy river bed in New Mexico with a Diabrotica tricincta Say (Chrysomelidae: Galerucinae).

\section{Entomognathus (Toncahua) memorialis Banks}

Ecology. Krombein (1963) characterized this species as a sylvicolous form which nests in rather heavy soil. He recorded specimens from Connecticut, New Jersey, Maryland, District of Columbia, Virginia, and Kansas. We observed small aggregations of this species flying near the tops of I-6-ft-high sand cliffs at Chittenango, Madison Co., N. Y. (Fig. I) during I9-28 August 1970 and I2 July I97I, and at Presque Isle St. Pk., Erie Co., Pa. from 4 to 9 July 1971. Both sites bordered bulldozed sandy fields near stands of deciduous northern hardwoods. At Chittenango, other sphecids nesting in the cliff included Philanthus politus Say, Oxybelus bipunctatus Oliv., O. emarginatus Say, and Xylocelia sp. Cliff-nesting sphecids at Presque Isle comprised Miscophus americanus Fox, Philanthus gibbosus (F.), and Xylocelia franclemonti Krom.

Mating Behavior. Ten males and three females were observed flying in front of the sand cliff at Presque Isle during the 6-day observation period. The males continuously circled a small Rubus plant at the base of the cliff and attempted to mate with small 
wasps, flies, and beetles as they landed on the leaves. They pursued females in flight and pounced upon them as they rested on the vegetation. One "mating ball" of three males and a female was seen tumbling over the sand until only one male remained whereupon the pair flew, still coupled, into the dense vegetation behind the cliff.

Nest-Site Selection. Although both males and females spent the night in pre-existing holes in the cliff, facing head-outward, these burrows were not utilized by the wasps for nest-sites. The females emerged from the holes between Io and I I a.m. and reentered them for the night between $2: 30$ and 3:30 p.m. The males were seen outside earlier in the morning and later in the afternoon than this. During the day females flew from one preexisting cavity to another, searching longest in root-shrouded areas near the top of the cliff. Occasionally, they climbed up the rootlets and sampled the soil with their mandibles. The males, on the other hand, investigated holes in the cliff only during late afternoon when they were looking for places to spend the night.

At Presque Isle females were out for nearly a week without one of them selecting a permanent nest-site or bringing in provisions. Seven males and three females observed at Chittenango on I2 July I97 I behaved similar to the wasps at Presque Isle, except for one female which entered a nest with prey.

Nest Structure. Seven nests of E. memorialis were excavated and studied at Chittenango. The entrances, $4.0-4.5 \mathrm{~mm}$ in diameter, were located among dense rootlets, 9.5-24.0 (mean 13.3 ) cm below the top of the cliff. A narrow, rather inconspicuous streak of sand extended down the slope beneath each entrance, indicating evidence of recent soil removal. The burrows, $3 \mathrm{~mm}$ in diameter, entered the outer sandy-loam at about right angles to the cliff and usually arched upward before descending into hard-packed sand in one or more undulations (Fig. 2a-d). The mean length of unobstructed burrow from the entrance was $16.8(9.5-27.0) \mathrm{cm}$. The distance from the entrance to the farthest cell in the nest via the burrow ranged from 9.5 to 29.0 (mean 21.2 ) $\mathrm{cm}$.

The four nests containing the largest number of cells (9-20) exhibited branching of the main burrow. The cells were arranged either singly, in fan-shaped clusters, or in series, with cells in tandem especially common. Tunnels from the main burrow to cells in clusters were not traceable, but those leading to and adjoining the cells in tandem were often loosely filled with sand and easily followed. The broadly oval cells averaged $4.4 \times 8.5 \mathrm{~mm}$ and ranged from $4 \times 6$ to $5 \times$ i3 $\mathrm{mm}(\mathrm{N}=29)$. They were located $13.5-25.0$ 


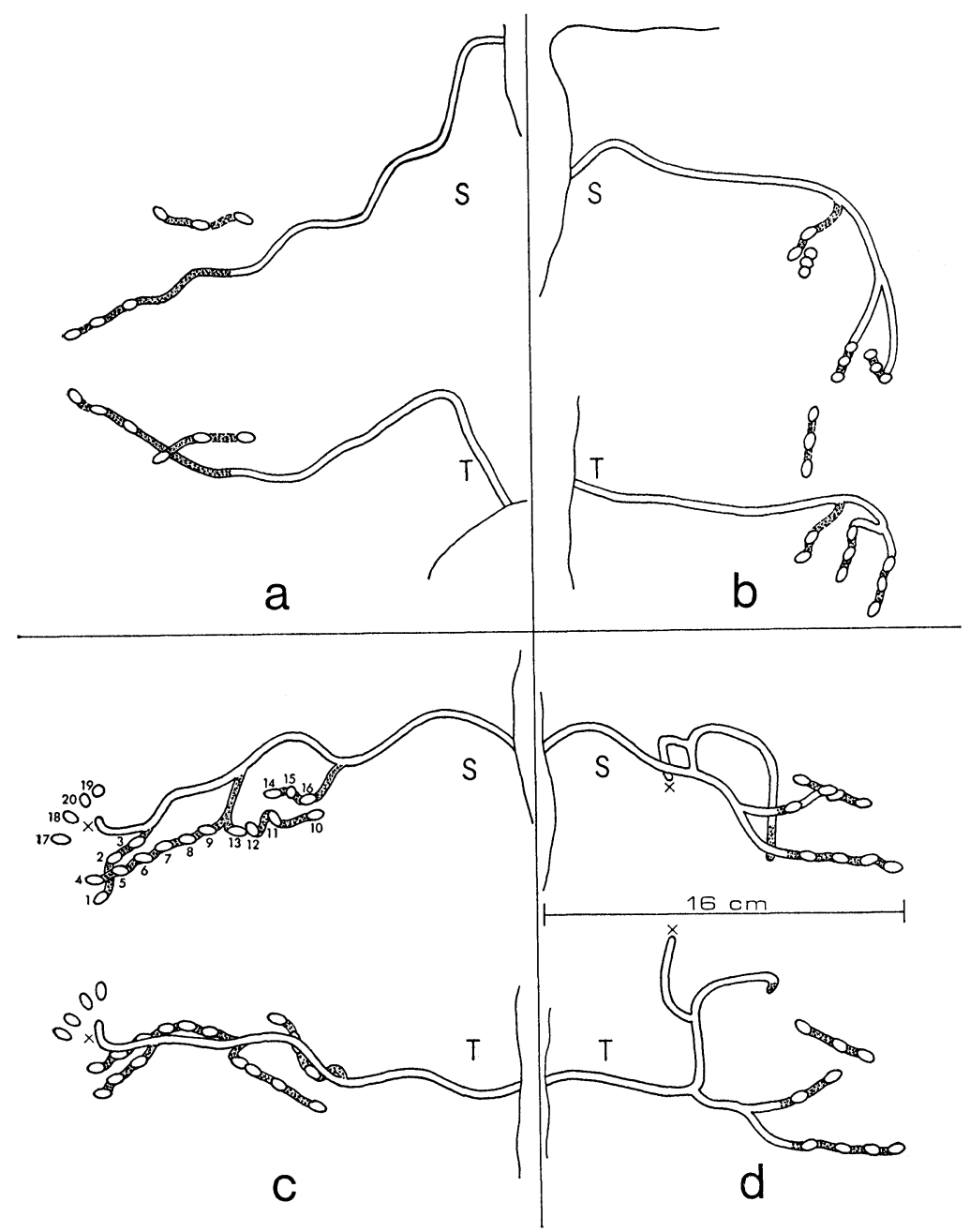

Fig. 2a-d. Side (S) and top (T) views of four nests of E. memorialis Banks; $x$ indicates burrow storage, numbers in (c) the sequence in which cells were provisioned. Stippling refers to sand fill. Scale for nest (d) applies to all nests. 
(mean $\mathrm{r} 8.8, \mathrm{~N}=74$ ) $\mathrm{cm}$ below the top of the cliff. Relative to the entrance, the cells were found from $2.5 \mathrm{~cm}$ above its level to 13.5 $\mathrm{cm}$ below it, averaging $5.5 \mathrm{~cm}$ below. The horizontal distance from the cliff face to a cell averaged I $2.2(4.5-21.5, N=66) \mathrm{cm}$.

The number of cells per nest ranged from 3 to 20 (mean I0.7). Except for cells in tandem, there was no correlation between the age of the cell and its position in the nest. In each tandem series, the cell farthest from the entrance in terms of total burrow length was the oldest. Because cells in series occasionally curved back toward the entrance, an older cell was sometimes closer to the entrance than a newer one in absolute distance (Fig. $2 b, c$ ). In nests $I$ and 2 (Fig. 2a, b), the female moved farther away from the entrance as she constructed new series of cells. In nest 3 (Fig. 2c), worked on by two females in succession, the first wasp apparently constructed tandem series toward the entrance whereas the second one built a series of three cells near the front and then a fan-shaped cluster of four cells at the back.

Transport and Storage of Prey. A provisioning female returned to her nest in flight, holding the beetle head-forward and venter-up with the middle legs. She usually hovered briefly in front of the cliff face before diving into the open entrance. The myriad of rootlets frequently made entry difficult and may have been responsible for many of the abandoned prey found beneath the entrances.

The single hunting time recorded was $3 \mathrm{~min}$. I $5 \mathrm{sec}$. The same female twice took $2 \mathrm{~min}$. to store a prey and return to the entrance. Temporary storage of beetles in the burrow at some distance from the entrance was recorded for three of the seven nests (Fig. $2 c, d)$. Such prey were placed head-inward and were loosely covered with sand particles. All of the beetles were partially paralyzed and moved their antennae and legs or flexed their elytra.

Nest provisions. Prey taken from the Chittenango nests in 1970 were determined as Altica ulmi Woods (Chrysomelidae: Alticinae). Two specimens collected from nests at this locality in July and August 197 I proved also to be this species. E. J. Kurczewski (correspondence) took a memorialis female with $A$. marevagans Horn at Presque Isle in August 197I. Of the $220 \mathrm{~A}$. ulmi preserved for identification, $46.8 \%$ were females and $53.2 \%$ males.

The mean number of prey per cell was 5.I $(3-9, N=42)$. The total weight of the beetles per cell in 13 fully-provisioned cells ranged from I 6.8 to 54.5 (mean 27.0) $\mathrm{mg}$. Individual beetles weighed from 3.7 to 8.0 (mean $5.4, \mathrm{~N}=68$ ) $\mathrm{mg}$, whereas one female wasp weighed $7.0 \mathrm{mg}$. The beetles in the cells were positioned head- 

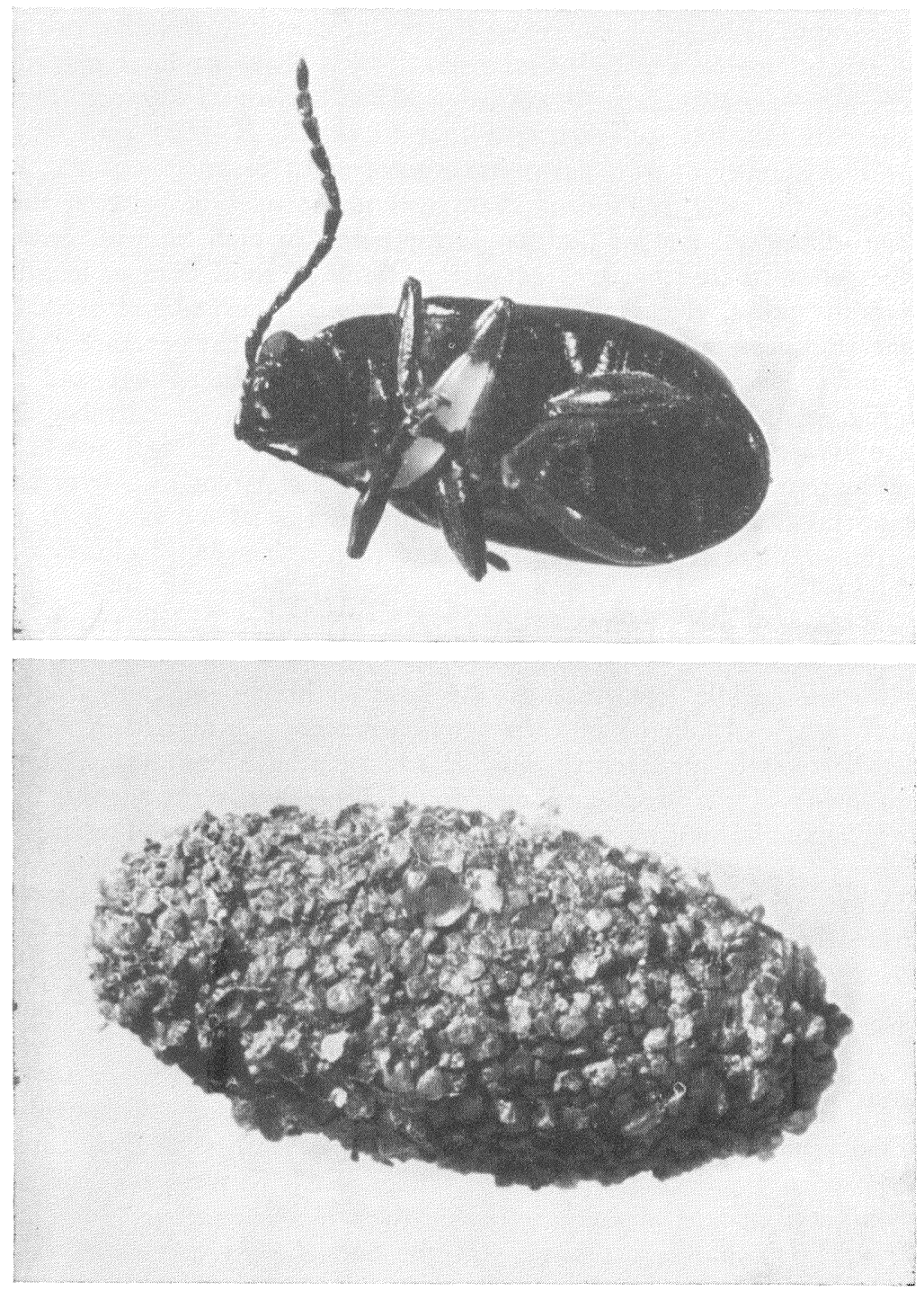

Fig. 3. (above). ô Altica ulmi Woods bearing egg of E. memorialis Banks in typical position.

Fig. 4. (below). Cocoon of E. memorialis Banks. 
inward and ventral-side-upward or, less commonly, dorsal-sideupward or on the side. The egg-bearing beetle was located at the back end of the cell and was placed venter-up or pressed obliquely against the wall.

In several nests, cells contained fresh or moldy prey but no egg, larva, or parasites. In three cases, abandoned prey were found buried in the sand plug which sealed off a fully-provisioned cell. Four beetles were entombed in single file in the loose sand in front of a cell containing six prey and an egg. The elytra of one beetle served as a wall-like barrier to the cell.

Egg and Immature Stages. The curved, hyaline egg, I.5-mm-long, was attached by the cephalic end to the anterolateral mesosternum near one of the procoxae (Fig. 3). It extended transversely but somewhat obliquely across the mesosternum, the free end lying above one of the anterolateral corners of the metasternum. Several mature larvae were reared and are described later in this paper. The brown, ellipsoidal cocoons averaged $2.5 \times 5.5 \mathrm{~mm}$ and consisted of silk, saliva, and sand grains (Fig. 4). The uneaten prey fragments were not embedded in the cocoon but were pushed to one end of the cell by the larva.

Nest Repossession and Renovation. During 19-28 August 1970, several females were provisioning nests at Chittenango but no males were seen. Other females were observed searching in holes and crevices rather than bringing in prey. Two of the wasps persisted in entering, backing out of, hovering in front of, and reentering certain burrows. Providing an appropriate site is found, such wasps may repossess and add to nests used earlier in the season by other females. In fact, nest 3 (Fig. 2c) with recently-captured beetles in the burrow also contained a dead memorialis female sealed off by loose sand at the end of the main burrow. Cells $\mathrm{I}-\mathrm{I} 3$ housing cocoons or nearly mature larvae were probably made by the first female before she died, whereas cells I 4-20 with recently-captured prey and eggs were probably made by the new occupant. In another nest, containing mostly old cells, a dead memorialis female was found deep in the burrow but she was not sealed off with sand. This nest, now being occupied by another female, held some recently completed cells and three beetles in burrow storage.

\section{Description of the Mature Larva}

Six mature larvae from Chittenango which were preserved in Kahle's solution and later transferred to $70 \%$ alcohol were utilized in the following description. None of the larvae had begun to spin 


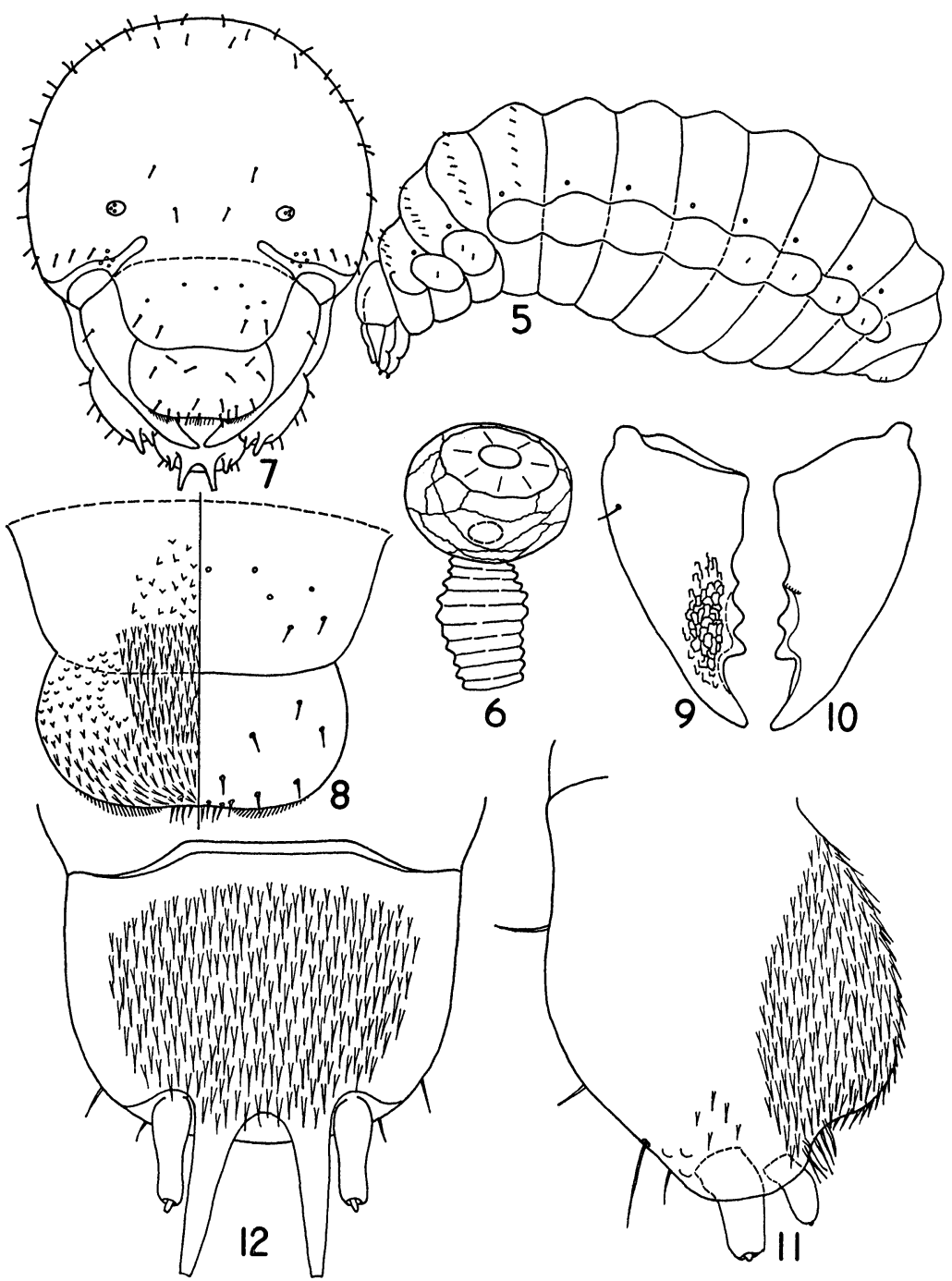

Figs. 5-12. Mature larva of E. memorialis Banks. 5. Lateral view of entire larva. 6. Thoracic spiracle. 7. Head in frontal view. 8. Clypeus and labrum (right), epipharynx (left). 9. Dorsal view of right mandible. 10. Ventral view of right mandible. 11. Dorsal view of right maxilla. 12. Dorsal view of prementum of labium. 
cocoons. Specific parts examined under the microscope were boiled briefly in $\mathrm{KOH}$ and then mounted in glycerine.

Body (Fig. 5). Length $7 \mathrm{~mm}$; maximum width $2.5 \mathrm{~mm}$. Stout, slightly curved, fusiform to subclavate, greatest width somewhat beyond middle; pleural lobes prominent, broadly rounded, those on meso- and metathorax oblique and more protuberant; penultimate abdominal segment with small pleural lobe; anus ventral, preapical and directed ventrad, anal segment rounded smoothly beyond anus; integument clothed with abundant minute spinules and sparse setae confined mainly to dorsum and pleural lobes; pronotum, mesonotum and metanotum with transverse series of $\mathrm{I} 2$ or 13 setae along dorsal ridge which is free of spinules, thoracic pleural lobes without spinules but with 2 or 3 setae, longest seta on thorax about $58 \mu$; first abdominal tergite with transverse row of Io setae, the longest $35 \mu$; other tergites without conspicuous setae; sternites uniformly and thoroughly clothed with minute spinules; spiracles (Fig. 6) small, weakly pigmented, posterior ones slightly smaller than anterior ones; thoracic spiracular atrium $55 \mu$ in diameter, weakly lined with anastomosing non-spinose ridges to form irregular polygons, opening into atrium surrounded by circular, non-sculptured area, entrance to subatrium simple and unarmed.

Head (Fig. 7). Height .80 mm, excluding labrum; width .82 $\mathrm{mm}$. Coronal suture and parietal bands apparently lacking; front with two oval longitudinal impressions between antennal orbits; epistomal suture indistinct, indicated by a weak transverse impression; antennal orbits subcircular, $45-50 \mu$ in diameter, antennal papillae lacking, three sensilla in equilateral triangle arising from membrane at lateral margin of orbit. Setae on head numerous, 40 of them distributed rather uniformly on sides and top and above bases of mandibles, only 4 setae on frons between antennal orbits, the longest $49 \mu$; clypeus (Fig. 8) with transverse row of 4 setae and basal transverse series of 7 or 8 minute "sensory" convexities; head weakly pigmented except for anterior tentorial arms and mandibles.

Mouthparts. Labrum (Fig. 8) $.39 \mathrm{~mm}$ wide, truncate, with about I 8 setae $28 \mu$ long, distributed laterally and anteriorly, several smaller setae extending from apical margin medially; apical margin bristly except in center; apex of oral surface with median pair of minute sensory pegs arising from circular pores; epipharynx papillose on basal lateral areas but spinulose elsewhere, center with stout, somewhat raised spinules arranged in semicircular pattern; apical 
spinules more slender and appressed; small oval area apparently free of pores or sensory structures at each side of central patch of spinules. Mandible (Figs. 9, IO) .4I $\mathrm{mm}$ long, .20 $\mathrm{mm}$ wide near base, with single basal seta; inner margin with four distinct rounded teeth in about the same plane and decreasing in size from apex to base; basal tooth blunt and transverse; conspicuous, broadly-rounded laminar protuberance between and ventral to second and third teeth; dorsal surface with polygonal sculpturing near teeth.

Maxilla (Fig. I I) strongly and broadly produced mesally, but not angulately so, inner margin densely spinulose, spinules moderately long and appressed; lacinial area with conspicuous tuft of long slender erect spinules; outer margin with four or five strong lateral setae of maximum length $46 \mu$; palpus $50 \mu$ long, stouter than galea which is $28 \mu$ long. Hypopharynx a broad lobe with strong dense spinules.

Labium (Fig. I2) with oral surface of prementum completely clothed with moderately long spinules of maximum length i9 $\mu$, spinules not separated into patches; base of prementum strongly sclerotized on oral side and separated from remainder of labium by distinct suture; palpi $43 \mu$ long, exceeded by paired spinnerets which are $73 \mu$ long, spinnerets slender and truncate apically.

\section{Discussion}

Entomognathus can be categorized as a genus of chrysomelidhunters, based upon the prey records presented in this paper. Thus far there is no species overlap in the genera of Chrysomelidae preyed upon. The European $E$. brevis is the most polyphagous species which has been studied, preying upon no less than I7 species of Alticinae and Cryptocephalinae (Table I). The North American $E$. (Toncahua) texanus captures galerucine leaf-beetles, whereas $E$. (Toncahua) memorialis preys upon alticine leaf-beetles. One prey species of the latter, $A$. ulmi, has been reported to feed in the field only on Ulmus americana, the American elm (Woods, I918). Nevertheless, we were unable to discover where hunting and prey capture took place. A second prey species, A. marevagans, has been collected on Oenothera biennis, the evening primrose (J. A. Wilcox, correspondence). The fact that slightly more males than females were taken by $E$. memorialis is puzzling in view of Blatchley's (I9IO) statment that males of Altica are "much less abundant than the females."

The prey of $E$. memorialis is relatively large compared to that of some other crabronine wasps. For example, mean prey/wasp 
weight ratios, expressed as decimals, for E. memorialis, Crossocerus maculiclypeus (Fox), and Lindenius columbianus errans (Fox) were $0.77,0.22$, and 0.07 , respectively. This point should not be stressed, however, because the weight of the female wasp may vary depending upon her physical condition (see Iwata, 1942). We caught a female of Cerceris fumipennis Say (Sphecidae) at Auburn, N. Y., weighed, released, and recaptured her 12 days later, and found that her body weight had decreased from 95 to $74 \mathrm{mg}$, or $22 \%$ !

Many fully-provisioned cells of $E$. memorialis lacked an egg, larva, or parasites, and we believe this may also be related to the physiological state of the female. Because they were excavated late in the nesting season, such cells were possibly made by females which had already exhausted their egg supplies.

The rather small mean number of prey per cell recorded for E. memorialis (5.I) is undoubtedly related to the relatively large mean sizes of the beetles. E. brevis constructs a cell of similar size but stores, on the average, considerably more ( I 7.8 ), usually smaller beetles per cell. There is, in fact, no overlap in the ranges of the number of prey per cell for brevis (14-24) and memorialis (3-9).

Several other differences in nesting behavior are evident between brevis and memorialis, particularly in nest structure and dimensions. Projecting turrets have been noted for nests of the former but not for nests of the latter. Series of cells in tandem are common in nests of memorialis but have not been observed in nests of brevis. The maximum number of cells per nest in memorialis (20) is twice as high as that reported for brevis (IO). The burrows of the former are longer than those of the latter, and the nests are more complicated. Although both species place the egg transversely across the mesosternum of the beetle, the cephalic end is attached mesad to the base of the procoxa in brevis (see Fig. II in Grandi, I927), whereas in memorialis it is fastened laterad of the base of the procoxa (Fig. 3). Furthermore, the caudal end of the egg extends beyond the side of the beetle in brevis while in memorialis it does not.

Several noteworthy similarities in the nesting behaviors of brevis and memorialis may be applicable for the entire genus. Both species paralyze their prey, probably by stinging, and enter their nests in flight, holding the beetle with the middle legs. The burrow storage of prey observed in memorialis is similar to that reported by Maneval (1937) for brevis. The burrow-searching adults of brevis observed by Adlerz (I9I2) may play a role similar to that 
of the memorialis females we implicated in nest repossession and renovation. The egg-bearer is placed venter-up in the cell in both species. The larvae of both species push the uneaten prey remains to one end of the cell rather than distributing them evenly over the surface of the cocoon as in Lindenius and certain Crabro spp.

A comparison of the mature larva of brevis, based upon Grandi's (1927) study, with that of memorialis reveals many similarities and only few differences. The base of the prementum of memorialis is rather truncate on the oral side, whereas that of brevis is strongly rounded. The conspicuous tuft of long, erect setae on the lacinial area of memorialis is apparently lacking in brevis. The spinules on the inner margin of the maxilla and the oral surface of the prementum of brevis are shorter and finer than those of memorialis. These differences are seemingly minor and may represent differences in preparation of the material or artistic rendition rather than genuine specific differences.

Our study of $E$. memorialis confirms several behavioral similarities between this genus and the larrine genus Bothynostethus which were pointed out in a paper on the nesting behavior of B. distinctus Fox by Kurczewski and Evans (1972). The most important of these homologies appear to be transverse, "larrine-like" egg placement and the habit of preying upon adult Chrysomelidae. Other ethological similarities between $E$. memorialis and $B$. distinctus include nesting in sand-cliffs among rootlets, transporting the prey in flight, storing an equivalent number of beetles per cell (mean 5), and placing the egg-bearing prey head-inward and venter-up at the innermost end of the cell.

Several differences in nesting behavior between $E$. memorialis and $B$. distinctus are noteworthy. According to Kurczewski and Evans, $B$. distinctus apparently constructs short branching side burrows from pre-existing galleries made by other insects, resulting in a highly variable nest structure. E. memorialis builds undulating, descending burrows with cells in tandem series or clusters around the distal half of the main burrow. Although $B$. distinctus also apparently holds the beetle with the middle legs in flight, it carries the prey dorsum-up and utilizes its mandibles to grasp the beetle's antennae. E. memorialis carries the prey venter-up but does not use the mandibles in transport. Burrow storage of prey, a feature typical of many crabronines, has been observed in the latter species and in E. brevis but not in B. distinctus. The completed cocoon of Entomognathus is entirely free of prey remains, whereas that of 
B. distinctus contains several beetle elytra firmly embedded at one end.

The mature larvae of Entomognathus and Bothynostethus have been compared by Kurczewski and Evans (1972). They noted a pair of finger-like lobes on the prothorax, fewer head setae, and three- rather than four-toothed mandibles in $B$. distinctus. It should also be noted that both E. memorialis (Fig. IO) and E. brevis have in addition to the four teeth along the inner margin of the mandible a conspicuous rounded laminar protuberance ventrad of the second and third teeth. This protuberance is lacking in $B$. distinctus. The maxilla of $B$. distinctus is evenly rounded on the inner margin, whereas that of both E. memorialis (Fig. II) and E. brevis (Grandi, 1927) is strongly and broadly produced.

The structural features of the maxilla and mandible of Entomognathus tentatively serve to distinguish this genus from all other genera of Sphecidae whose larvae have been described. Our confidence in these characters has been strengthened by comparing recently-collected mature larvae of crabronines in the genera Lindenius, Crossocerus, and Anacrabro with the illustrations and descriptions of species in these genera prepared by Evans (1957, 1959).

In summary, comparison of the European E. (Entomognathus) brevis with the North American E. (Toncahua) memorialis revealed few significant differences in nesting behavior and substantiated congenerity. Comparing the nesting ethology of the latter crabronine with the larrine Bothynostethus distinctus brought to light some striking similarities and rather significant differences.

Differences in the morphology of the mature larvae of species of Entomognathus are even more subtle than differences in nesting behavior. Comparison of E. brevis, as depicted by Grandi (1927), with E. memorialis disclosed few, if any, real differences. The larvae of Entomognathus and Bothynostethus are, likewise, rather similar and support Evans' (1958, 1959, 1964) belief that the sphecid subfamilies Crabroninae and Larrinae are much more closely related than is currently indicated in the Hymenoptera of America North of Mexico Synoptic Catalog (Muesebeck, et al., 195I; Krombein, 1958; Krombein and Burks, 1967).

The cocoon of Bothynostethus is more crabronine than larrine and that of Entomognathus, the reverse, based upon comparisons with cocoons of Lyroda, Plenoculus, Tachytes, and Tachysphex in the Larrinae and Lindenius and certain Crabro in the Crabroninae. 


\section{ACKNOWLEDGMENTS}

We are indebted to J. A. Wilcox, New York State Museum and Science Service, and to A. S. Menke, Systematic Entomology Laboratory, USDA, for identifying the beetles and wasps, respectively. We also thank D. B. Peckham for translating Grandi's (1927) article on Entomognathus brevis, D. J. Peckham for photographing the egg attachment and cocoon of E. memorialis, and S. and A. Panebianco of Pine Ridge Farms Potatoes, Chittenango, N. Y., for allowing us to utilize their property in our study. E. J. Kurczewski, of Erie, Pa., kindly furnished us with a prey record for E. memorialis from Presque Isle St. Pk. Funds, in part, for this study were provided by a Grant-in-Aid from the Research Foundation of the State University of New York (No. I0-7 I 16-A).

\section{References Cited}

Abrahamsen, S. E.

1951. Nyere undersøgelser over danske gravehvepses biologi. Flora og Fauna 57: 115-130.

AdLerz, G.

1912. Lefnadsförhållanden och instinkter inom familjerna Pompilidae och Sphegidae. IV. K. Svenska Vet. Ak. Handl. 47: 1-61.

Arnold, G.

1932. New species of Ethiopian Sphegidae. Occ. Pap. Rhod. Mus. 1: 1-31.

1944. The Sphecidae of Madagascar. Trust. N. Mus. S. Rhodesia. Benoist, R. Cambridge Univ. Press, England, 193 pp.

1915. Sur l'Entomognathus brevis Lind. (Sphegidae), Hyménoptère chasseur d'Altises. Bull. Soc. Ent. Fr. 20: 241-242.

BLATCHLEY, W. S.

1910. An illustrated descriptive catalogue of the Coleoptera or beetles (exclusive of the Rhynchophora) known to occur in Indiana. Indianapolis, Ind., Nature Publ. Co. 1386 pp.

BouWman, B. E.

1930. De Graafwespen van Nederland. Levende Natuur 35: 64-69, 98-108.

Cazier, M. A. and M. A. Mortenson.

1965. Studies on the bionomics of sphecoid wasps. V. Bothynostethus distinctus and Entomognathus texana (Hymenoptera: Sphecidae). Pan-Pacif. Ent. 41 : 30-33.

Chambers, V. H.

1949. The Hymenoptera Aculeata of Bedfordshire. Trans. Soc. Brit. Ent. 9: 197-252.

Evans, H. E.

1957. Studies on the larvae of digger wasps (Hymenoptera, Sphecidae). Part III: Philanthinae, Trypoxyloninae, and Crabroninae. Trans. Amer. Ent. Soc. 83 : 79-117. 
1958. Same title. Part IV: Astatinae, Larrinae, and Pemphredoninae. Trans. Amer. Ent. Soc. 84: 109-139.

1959. Same title. Part V. Conclusion. Trans. Amer. Ent. Soc. 85: 137-191.

1964. The classification and evolution of digger wasps as suggested by larval characters (Hymenoptera: Sphecoidea). Ent. News 75 : 225-237.

Grandi, G.

1927. Contributi alla conoscenza degli Immenotteri melliferi e predatori. II. Documenti etologicie morfologici sul Crabro (Entomognathus) brevis v. d. Lind. Crabronide predatore di Alticidi. Redia 16: 69-78.

1931. Contributi alla conoscenza biologica e morfologica degli Immenotteri melliferi e predatori. XII. Boll. Lab. Ent. Bologna 4: 19-72.

Hamm, A. H. and O. W. Richards.

1926. The biology of the British Crabronidae. Trans. Ent. Soc. London 74: 297-331.

IWATA, K.

1942. Comparative studies on the habits of solitary wasps. Tenthredo 4: $1-146$.

KROMBEIN, K. V.

1958. Hymenoptera of America north of Mexico. Synoptic Catalog. First Supplement. USDA Agric. Monogr. 2: 1-305.

1963. Notes on the Entomognathus of eastern United States (Hymenoptera: Sphecidae). Proc. Biol. Soc. Wash. 76: 247-254.

Krombein, K. V. and B. D. BURKs.

1967. Hymenoptera of America north of Mexico. Synoptic Catalog. Second Supplement. USDA Agric. Monogr. 2: 1-584.

KURCZewski, F. E. ANd H. E. Evans.

1972. Nesting behavior and description of the larva of Bothynostethus distinctus Fox (Hymenoptera: Sphecidae). Psyche, 79: 88-103.

LECLERCQ, J.

1954. Monographie systématique, phylogénétique et zoogéographique des Hyménoptères Crabroniens. Thèse, Fac. Sci. Univ., Liege. $371 \mathrm{pp}$.

1955. Entomognathus (Toncahua) geometricus, crabronien nouveau de Panama (Hym. Sphecidae). Bull. Ann. Soc. R. Ent. Belg. 91: 193-195.

1961. Sphecoidea: Sphecidae subfam. Sphecinae, Pemphredoninae et Crabroninae. Explor. Parc. Nat. Garamba, Miss. de Saeger, 19491952, $20: 43-105$.

1963. Crabroniens d'Asie et des Philippines (Hymenoptera, Sphecidae). Maneval, $\mathrm{H}$. Bull. Ann. Soc. R. Ent. Belg. 99: 1-82.

1928. Notes sur quelques Hyménoptères Fouisseurs. Bull. Soc. Ent. Fr. $33: 29-32$.

1937. Notes sur les Hyménoptères (5e série). Rev. Fr. Ent. 4: 162-181. Muesebeck, C. F. W., et al.

1951. Hymenoptera of America north of Mexico. Synoptic Catalog. USDA Agric. Monogr. 2: 1-1420. 
Nouvel, H. and H. Ribaut.

1956. Une espèce francaise nouvelle du genre Entomognathus (Hymenoptera, Sphecidae). Bull. Soc. His. Nat. Toulouse 91: 263-265. Richards, O. W.

1944. Observations on Aculeate Hymenoptera. Proc. R. Ent. Soc. London (A) 19: 133-136.

SickMANN, F.

1893. Die Hymenopteren-fauna von Iburg under seiner nächsten Umgebung, mit biologischen und kritischen Bemerkungen. I. Abteilung die Grabwespen. Jahresber. nat. Ver. Osnabrück 9: 39-112.

Woops, W. C.

1918. The biology of the Maine species of Altica. Maine Agric. Exp. Sta. Bull. 273 : 149-204. 

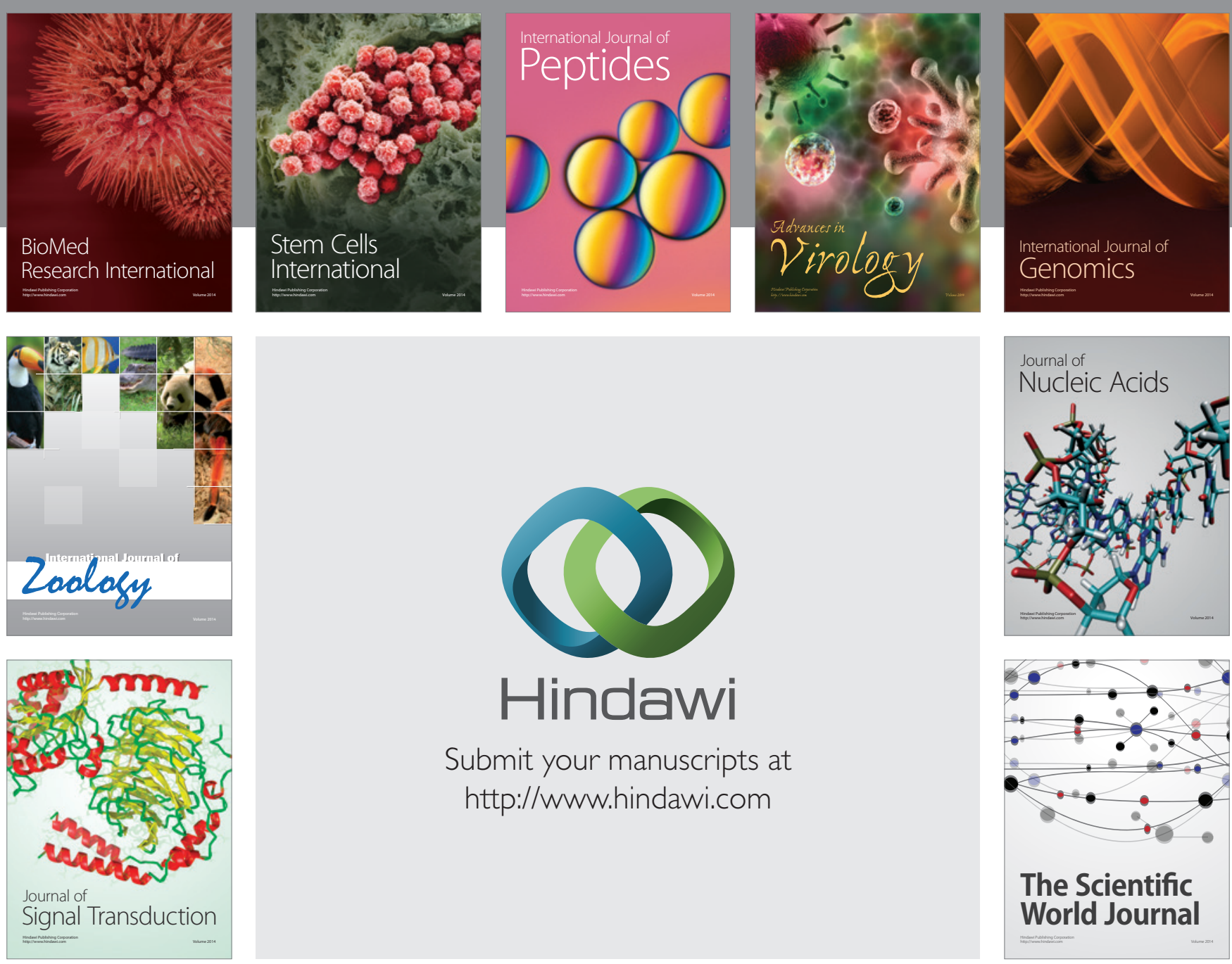

Submit your manuscripts at

http://www.hindawi.com
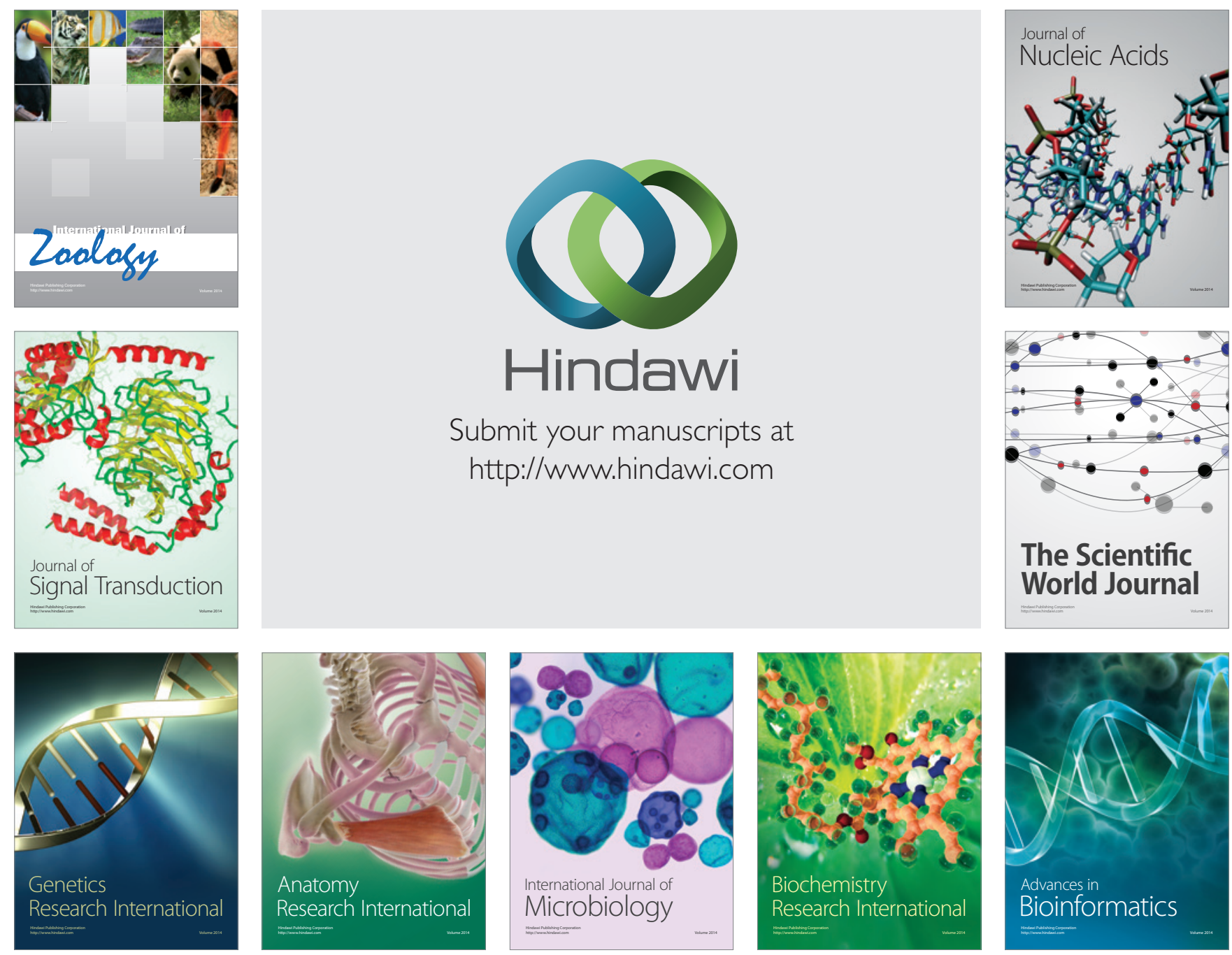

The Scientific World Journal
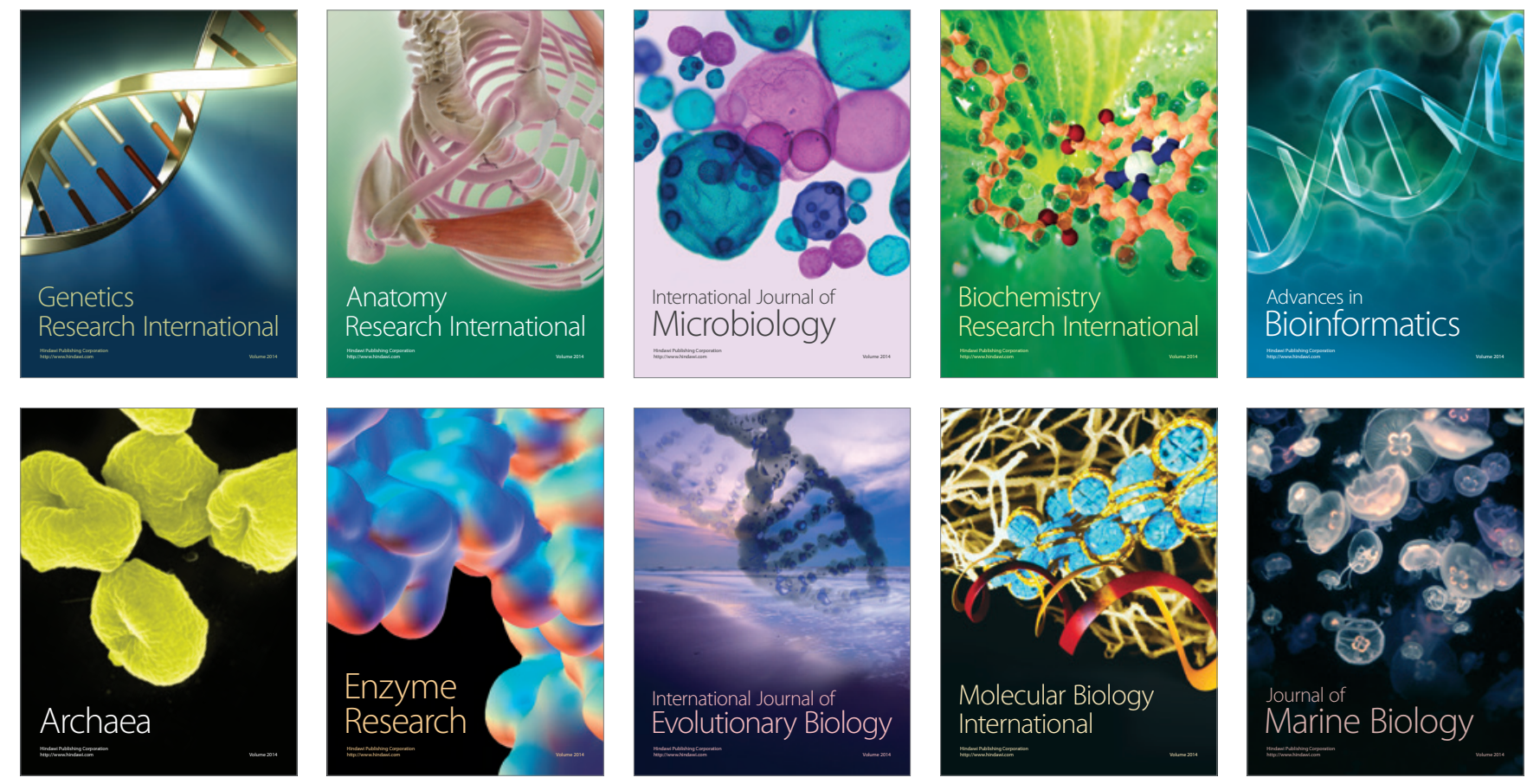